\title{
Fructokinase activity in rat liver, ileum, parotid gland, pancreas, pancreatic islet, $B$ and non- $B$ islet cell homogenates
}

\author{
MARIE-HELENE GIROIX ${ }^{1}$, HASSAN JIJAKLI ${ }^{2}$, PHILIPPE COURTOIS ${ }^{2}$, \\ YING ZHANG $^{2}$, ABDULLAH SENER ${ }^{2}$ and WILLY J. MALAISSE ${ }^{2}$ \\ ${ }^{1}$ Laboratory of Nutrition Physiopathology, CNRS UMR 7059, University of Paris 7, Paris, France; \\ ${ }^{2}$ Laboratory of Experimental Hormonology, Brussels Free University, Brussels, Belgium
}

Received November 10,2005; Accepted December 28, 2005

\begin{abstract}
The presence of fructokinase (ketohexokinase) in rat pancreatic islet homogenates was previously documented. However, no information was so far available on the activity of this enzyme in islets relative to that in other tissues and on the respective contribution of insulin-producing B cells and non-B islet cells. The present study provides such an information. The activity of fructokinase, as assessed by the phosphorylation of $1.0 \mathrm{mM}$ D-fructose, was compared to that of hexokinase isoenzyme(s), as measured in the presence of $1.0 \mathrm{mM} \mathrm{D}$ glucose, and further characterized by its heat-resistance, $\mathrm{K}^{+}$ dependency and resistance to the inhibitory action of D-mannoheptulose. As judged from the results obtained in heated homogenates, the activity of fructokinase, expressed relative to protein content (nmol/min per mg protein) was highest in liver $(21.5 \pm 2.5 ; \mathrm{n}=11)$ and lowest in parotid gland $(0.16 \pm 0.09$; $\mathrm{n}=3)$, with in-between values in ileum $(2.45 \pm 0.53 ; \mathrm{n}=3)$, pancreas $(0.82 \pm 0.11 ; \mathrm{n}=11)$ and pancreatic islets $(0.46 \pm 0.07$; $\mathrm{n}=6$ ). The paired ratio between fructokinase and hexokinase isoenzyme activity was also highest in liver $(548 \pm 45 \% ; n=8)$ and lowest in parotid gland $(0.93 \pm 0.52 \% ; n=3)$. Such a ratio was not significantly different in pancreas, islets and purified $\mathrm{B}$ or non-B islet cells, with an overall mean value of $2.57 \pm 0.46 \%$ $(n=12)$. The present findings thus unambiguously document the presence of fructokinase activity in all cell types under consideration, except possibly parotid cells, with the following hierarchy: liver $>$ ileum $>$ pancreas. Relative to paired hexokinase activity, no obvious difference was found for fructokinase activity in B versus non-B islet cells.
\end{abstract}

\section{Introduction}

Over the last two decades, several studies aimed at investigating the metabolism and insulinotropic action of D-fructose in

Correspondence to: Professor Willy J. Malaisse, Laboratory of Experimental Hormonology, Brussels Free University, 808 Route de Lennik, B-1070 Brussels, Belgium

E-mail: malaisse@ulb.ac.be

Key words: fructokinase, hexokinase, liver, pancreatic islets, B and non-B islet cells pancreatic islets. In terms of metabolism, attention was drawn to the participation of different enzymes to the phosphorylation of the ketohexose, including fructokinase (1), the low-Km hexokinase (2), and the high-Km glucokinase with emphasis on the glucose-induced cooperativity of this enzyme towards D-fructose $(3,4)$ and the anomeric specificity of such a process $(5,6)$. The possible participation of D-fructose 1-phosphate in the regulation of glucokinase activity at the intervention of its regulatory protein (7) was also examined (Iwashiga $\mathrm{K}$, et al, Diabetologia 38 (Suppl 1): abs. 394, A102, 1995) (8). In terms of stimulus-secretion coupling, puzzling findings relate to the dissociation both between the effects of D-fructose on proinsulin biosynthesis and insulin release (9) and between the changes evoked by the ketohexose in the ATP and ADP content, as well as ATP/ADP ratio, and its insulinotropic action (Giroix M-H, et al, Diabetologia 47 (Suppl 1): abs. 457, A168, 2004) in isolated islets. From the physiological standpoint, a recent study revealed that both the immediate and delayed effects of D-fructose, as compared to D-glucose, upon secretory activity may differ in insulin-, somatostatinand glucagon-producing cells (10). The possible participation of D-fructose insulinotropic action in the improvement of Dglucose tolerance evoked in vivo by the ketohexose was also investigated (11). Last, in terms of the perturbation of islet function in type 2 diabetes, several studies aimed at comparing the fate of $\mathrm{D}$-fructose in islets obtained from either control rats or animals currently used as models for this disease (12-14).

The present study deals with one of these issues, i.e. the activity of fructokinase in rat pancreatic islets. In a prior study, it was already documented that rat islets indeed display fructokinase activity (1). The ATP-dependent phosphorylation of D-fructose in homogenates of rat pancreatic islets that had been heated for $5 \mathrm{~min}$ at $70^{\circ} \mathrm{C}$ in order to inactivate hexokinases was found to be dependent on the presence of $\mathrm{K}^{+}$and inhibited by D-tagatose. The phosphorylation product was identified as D-fructose 1-phosphate through its conversion to a bisphosphate ester by Clostridium difficile fructose 1-phosphate kinase (1). In this prior study, however, the fructokinase activity in islet homogenates was not compared to that found in other organs, and the respective contribution of B and non-B islet cells to such an activity was not investigated. The results of the present study provide this missing information. 


\section{Materials and methods}

D- $\left[\mathrm{U}-{ }^{14} \mathrm{C}\right]$ glucose and D- $\left[6-{ }^{14} \mathrm{C}\right]$ glucose were purchased from NEN Life Science Products (Boston, MA) and Amersham International (Aylesbury, UK), respectively. The radioactive D-fructose tracers (D-[U- $\left.{ }^{14} \mathrm{C}\right]$ fructose or D-[6- $\left.{ }^{14} \mathrm{C}\right]$ fructose) were prepared from the corresponding ${ }^{14} \mathrm{C}$-labelled $\mathrm{D}$-glucose using an alkaline isomerization procedure and were further purified by HPLC, as described elsewhere (15).

Adult albino Wistar rats of both sexes were given free access to tap water and a standard pellet chow (Km-04-K12; Pavan Service, Oud Turnhout, Belgium) up to the time of sacrifice. All animal experimentation was conducted in accordance with accepted standards of animal care, as established by the local animal experimentation ethics committee.

Islets were isolated from the pancreas of 3-6 rats using a collagenase (EC 3.4.24.3 from Clostridium histolyticum, type P; Roche Molecular Biochemicals, Mannheim, Germany) digestion technique (16) and subsequently separated from the remaining exocrine tissue by hand-picking under a stereomicroscope. Hanks' balanced salt solution saturated with a mixture of $95 \% \mathrm{O}_{2}$ and $5 \% \mathrm{CO}_{2}$ was used during the isolation procedure. Dispersed cells were prepared from isolated islets by incubation for $5-10 \mathrm{~min}$ at $30^{\circ} \mathrm{C}$ in a $\mathrm{Ca}^{2+}$-free Hepes- $\mathrm{NaOH}$ buffer containing neutral proteinase (EC 3.4.24.4, $0.48 \mathrm{mg} / \mathrm{ml}$ ) from Bacillus polymyxa (Dispase II; Boehringer Mannheim, Germany) and 2 populations of B and non-B cells, respectively, were obtained by immunomagnetic purification, as described elsewhere (17) using R2D6 monoclonal antibody directed against plasma membranes of rat pancreatic B cells (18).

The islets or islet cells were homogenized by sonication $(3 \times 10 \mathrm{sec})$ in a Hepes- $\mathrm{NaOH}$ buffer $(50 \mathrm{mM}, \mathrm{pH} 7.5)$ containing $60 \mathrm{mM} \mathrm{KCl}, 10 \mathrm{mM} \mathrm{KH}_{2} \mathrm{PO}_{4}$ and $6 \mathrm{mM} \mathrm{MgCl}_{2}$, except in the experiments performed in the absence of $\mathrm{K}^{+}$, in which case $\mathrm{KCl}$ and $\mathrm{KH}_{2} \mathrm{PO}_{4}$ were omitted, to yield 650 islets per $\mathrm{ml}$ and $0.9-1.8 \times 10^{6} \mathrm{~B}$ cells or $0.6-1.2 \times 10^{6}$ non-B cells per $\mathrm{ml}$.

For purpose of comparison, pieces of pancreas, liver, ileum and parotid gland were minced, sonicated and diluted in the above-mentioned buffer to yield 1-10 mg wet weight tissue per $\mathrm{ml}$. In one set of experiments the minced pieces of tissues were homogenized in Potter-Elvejhem tubes (30 strokes) and centrifuged for $60 \mathrm{~min}$ at $100,000 \mathrm{~g}$. When required, the homogenates were heated for $5 \mathrm{~min}$ at $70^{\circ} \mathrm{C}$.

For the measurement of D-glucose or D-fructose phosphorylation, aliquots $(50 \mu \mathrm{l})$ of the homogenates were mixed with the same volume of a reaction mixture prepared in the same buffer as that used to homogenize cells or tissues and containing $10 \mathrm{mM}$ ATP (sodium salt), $2 \mathrm{mM}$ of either Dglucose or D-fructose, mixed with a tracer amount $(2.0 \mu \mathrm{Ci} /$ $\mathrm{ml})$ of the ${ }^{14} \mathrm{C}$-labelled corresponding hexose (D-[U- $\left.{ }^{14} \mathrm{C}\right]$ glucose and either D-[U- $\left.{ }^{14} \mathrm{C}\right]$ fructose or D-[6- $\left.{ }^{14} \mathrm{C}\right]$ fructose), $0.4 \mathrm{mg} / \mathrm{ml}$ bovine serum albumin and, as required, $40 \mathrm{mM} \mathrm{D}$ mannoheptulose (CMS Chemical Ltd., Oxford, UK). After a 20 min incubation at $30^{\circ} \mathrm{C}$, the reaction was halted by adding $1.0 \mathrm{ml}$ of ice water, the diluted reaction mixture being then passed through a column $(0.5 \mathrm{ml})$ of AG1-X8 resin (chlorideform; Bio-Rad Laboratories, Inc., Hercules, CA, USA) for separation of the hexose phosphate(s), generated during incubation, by anion exchange chromatography (19). The column was successively rinsed with $3 \times 0.25 \mathrm{ml}$ and $5 \times 1.5 \mathrm{ml}$ of water. The hexose phosphate(s) were then eluted with $2 \times 1.5 \mathrm{ml}$ of a solution of $1.0 \mathrm{M}$ ammonium formate/0.1 M formic acid. The eluate was mixed with $8.0 \mathrm{ml}$ of scintillation fluid and its radioactive content measured. The results were calculated, after correction for the blank value obtained under identical conditions in the absence of cell or tissue homogenates, by reference to the specific radioactivity of the incubation medium. All measurements were performed in triplicate.

The protein content of the homogenates was measured as previously described (20), using bovine serum albumin as standard.

All results are presented as mean values ( \pm SEM), together with the number of individual observations (n) or degree of freedom (d.f.). The statistical significance of differences between mean values was assessed by use of Student's t-test.

\section{Results}

Liver. In non-heated liver homogenates, the phosphorylation of D-glucose $(1.0 \mathrm{mM})$ averaged $17.5 \pm 1.9 \%(\mathrm{n}=8 ; \mathrm{p}<0.001)$ of that found, within the same experiment(s) with D-fructose (also $1.0 \mathrm{mM})$. D-mannoheptulose $(20 \mathrm{mM})$ failed to affect the phosphorylation of D-fructose, which averaged $98.6 \pm 1.8 \%$ $(n=3 ; p>0.5)$ of the paired value found in the absence of the ketoheptose. The omission of $\mathrm{K}^{+}$in the assay medium, however, decreased D-fructose phosphorylation to $20.0 \pm 1.8 \%$ $(n=3 ; p<0.001)$ of the paired control value. Prior heating of the liver homogenates for $5 \mathrm{~min}$ at $70^{\circ} \mathrm{C}$ decreased D-glucose phosphorylation to $1.15 \pm 0.27 \%(\mathrm{n}=8 ; \mathrm{p}<0.001)$ of its paired control value. In the case of $\mathrm{D}$-fructose, however, such a percentage averaged $95.2 \pm 7.1 \%(n=11 ; p>0.5)$. Likewise, in the presence of D-mannoheptulose or absence of $\mathrm{K}^{+}$, the reaction velocity for $\mathrm{D}$-fructose phosphorylation averaged, after heating, $113.0 \pm 11.4 \%(n=4 ; p>0.3)$ of the paired value recorded in non-heated homogenates. Thus, pooling all available data, the phosphorylation of $\mathrm{D}$-fructose by heated homogenates averaged $100.0 \pm 6.2 \%(n=15 ; p>0.99)$ of the paired value found in fresh homogenates. These findings suggest that the phosphorylation of D-fructose by liver homogenates is attributable, at the low concentration of the ketohexose used in the present experiments, exclusively to a heat-resistant and $\mathrm{K}^{+}$-sensitive enzyme, presumably fructokinase. Moreover, the results indicate that the phosphorylation of D-fructose by fructokinase is resistant to inhibition by Dmannoheptulose.

Ileum. In non-heated homogenates of ileum segments, the phosphorylation of D-fructose $(1.0 \mathrm{~m})$ represented $64.2 \pm 6.8 \%$ $(\mathrm{n}=3 ; \mathrm{p}<0.05)$ of the paired value found with D-glucose (also $1.0 \mathrm{mM}$ ). After heating, the phosphorylation of D-glucose was decreased to $0.05 \pm 0.02 \%(n=3)$ of the paired value found in non-heated homogenates. Such a percentage only represented $0.48 \pm 0.28 \%(n=3 ; p<0.001)$ of that found, within the same experiment(s), in the case of D-fructose. Thus, a sizeable fraction of the phosphorylation of D-fructose by the non-heated ileum homogenates $(12.4 \pm 4.7 \% ; n=3)$ appeared attributable to a heat-resistant enzyme, presumably fructokinase. The 
remaining fraction of D-fructose phosphorylation by the nonheated homogenates was presumably catalyzed by a low-Km hexokinase.

Parotid cells. In non-heated homogenates of parotid glands, the phosphorylation of D-fructose $(1.0 \mathrm{mM})$ only represented $50.4 \pm 11.7 \%(\mathrm{n}=3)$ of that found within the same experiments with D-glucose (also $1.0 \mathrm{mM}$ ). The absolute values averaged $1364 \pm 283$ and $641 \pm 145 \mathrm{pmol} / \mathrm{min}$ per $\mathrm{mg}$ wet weight $(\mathrm{n}=3$ in both cases) with D-glucose and D-fructose, respectively. After 5 min heating at $70^{\circ} \mathrm{C}$, the phosphorylation of D-glucose was virtually abolished, averaging not more than $0.04 \pm 0.02 \%(n=3)$ of the paired value recorded before heating. In the case of Dfructose phosphorylation, such a percentage was increased to not more than $1.66 \pm 0.63 \%(n=3 ; p<0.07)$. These findings argue against the presence of any biologically significant amount of fructokinase in parotid glands. If so, the comparison of the results obtained in homogenates of parotid glands and other organs (e.g. liver) indicates that the heating procedure was indeed adequate to assess the possible presence of fructokinase in such homogenates.

Pancreas. In non-heated pancreatic homogenates, the phosphorylation of D-glucose and D-fructose (1.0 mM each), when expressed per mg wet weight, averaged $2.57 \pm 0.56(n=8)$ and $1.82 \pm 0.28(\mathrm{n}=11) \mathrm{nmol} / \mathrm{min}$. The phosphorylation of $\mathrm{D}$ fructose represented $72.8 \pm 7.8 \%(n=8 ; p<0.02)$ of the paired value found with D-glucose. D-mannoheptulose $(20 \mathrm{mM})$ decreased D-fructose phosphorylation to $7.7 \pm 1.7 \% \quad(n=3$; $\mathrm{p}<0.001$ ) of its paired control value (no D-mannoheptulose). In the absence of $\mathrm{K}^{+}$, however, the phosphorylation of $\mathrm{D}$ fructose averaged $98.8 \pm 0.9 \%(n=3)$ of the paired value found in the presence of $\mathrm{K}^{+}$. After heating for $5 \mathrm{~min}$ at $70^{\circ} \mathrm{C}$, the phosphorylation of D-glucose was decreased to $0.09 \pm 0.04 \%$ $(n=8)$ of the paired value found in fresh homogenates. In the case of D-fructose, however, a sizeable phosphorylating activity remained present in the heated homogenates. It averaged $89.7 \pm 10.4 \mathrm{pmol} / \mathrm{min}$ per $\mathrm{mg}$ wet weight $(\mathrm{n}=11)$, representing $6.96 \pm 1.56 \%(\mathrm{n}=11)$ of the paired value found in fresh homogenates. The latter percentage is obviously higher $(\mathrm{p}<0.005)$ than that recorded in the case of D-glucose. D-mannoheptulose $(20 \mathrm{mM})$ failed to affect significantly $(\mathrm{p}>0.8)$ the phosphorylation of D-fructose by the heated pancreas homogenates, in which case the reaction velocity averaged $74.1 \pm 16.4 \%(n=3$; $\mathrm{p}>0.2$ ) of the paired value found in fresh homogenates. The absence of $\mathrm{K}^{+}$decreased the phosphorylation of D-fructose by heated homogenates to $29.5 \pm 5.7 \%(n=3 ; p<0.01)$ of the paired value found in the presence of $\mathrm{K}^{+}$. In the absence of $\mathrm{K}^{+}$, the reaction velocity found in the heated homogenates averaged $1.70 \pm 0.39 \%(n=3)$ of the paired value found in fresh homogenates. The latter percentage only represented $29.9 \pm 5.9 \%$ $(n=3 ; p<0.01)$ of the paired value found in the presence of $\mathrm{K}^{+}$. These findings indicate that the major fraction of D-fructose phosphorylation by fresh pancreatic homogenates was attributable to D-mannoheptulose-sensitive and $\mathrm{K}^{+}$-independent enzyme(s), such as hexokinase isoenzyme(s). Nevertheless, the results recorded in heated pancreas homogenates reveal the presence of a sizeable heat-resistant, D-mannoheptuloseresistant and $\mathrm{K}^{+}$-dependent $\mathrm{D}$-fructose phosphorylating enzymatic activity, presumably fructokinase. The hierarchy

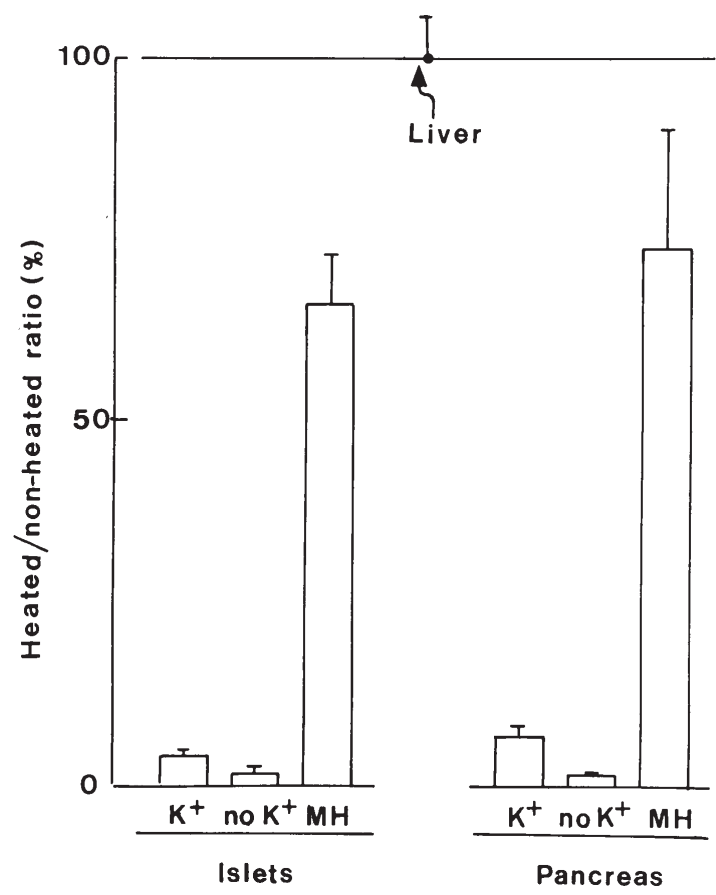

Figure 1. Paired ratio for the phosphorylation of D-fructose $(1.0 \mathrm{mM})$ by heated/non-heated homogenates of pancreatic islets and pancreatic glands incubated in the presence $\left(\mathrm{K}^{+}\right)$or absence $\left(\right.$no $\left.\mathrm{K}^{+}\right)$of potassium, and in the presence of $\mathrm{K}^{+}$and $20 \mathrm{mM}$ D-mannoheptulose $(\mathrm{MH})$. Mean values $( \pm \mathrm{SEM})$ refer to 3-11 individual determinations. The upper horizontal line refers to the measurements made in liver homogenates $(n=15)$, in which case the mean heated/non-heated ratios were not significantly different from one another under the three experimental conditions under consideration.

of the heated/fresh ratio in D-fructose phosphorylation, i.e. $74.1 \pm 16.4 \%$ in the presence of D-mannoheptulose, $7.0 \pm 1.6 \%$ in the absence of the ketoheptose but presence of $\mathrm{K}^{+}$and $1.7 \pm 0.4 \%$ in the absence of $\mathrm{K}^{+}$, further supports such a conclusion.

Pancreatic islets. In the next step, it was investigated whether the results recorded in whole pancreas homogenates may correspond, in part at least, to the presence of fructokinase in the endocrine moiety of the pancreatic gland. In non-heated islet homogenates, the phosphorylation of Dfructose $(1.0 \mathrm{mM})$ averaged $89.2 \pm 6.4 \%(\mathrm{n}=3 ; \mathrm{p}>0.2)$ of the paired value found with D-glucose (also $1.0 \mathrm{mM}$ ). The major fraction of D-fructose phosphorylation by the fresh islet homogenates appeared attributable to hexokinase isoenzyme(s). In the non-heated islet homogenates, the phosphorylation of D-fructose was decreased to $8.2 \pm 1.5 \%(n=3 ; p<0.001)$ of its paired control value by D-mannoheptulose $(20 \mathrm{mM})$, but not significantly affected $(\mathrm{p}>0.95)$ in the absence of $\mathrm{K}^{+}$, in which case the reaction velocity averaged $99.8 \pm 3.9 \%(n=3)$ of the paired value found in the presence of $\mathrm{K}^{+}$. A vastly different situation prevailed in heated islet homogenates. Thus, in this case, the mean reaction velocity was virtually identical in the absence $(456 \pm 8 \mathrm{fmol} / \mathrm{min}$ per islet) and presence $(457 \pm 139$ $\mathrm{fmol} / \mathrm{min}$ per islet; $\mathrm{n}=3$ in both cases) of $\mathrm{D}$-mannoheptulose $(20 \mathrm{mM})$, but decreased $(\mathrm{p}<0.05)$ to about one-third of its paired control value $\left(\mathrm{K}^{+}\right.$present) in the absence of $\mathrm{K}^{+}$ $(146 \pm 107 \mathrm{fmol} / \mathrm{min}$ per islet; $\mathrm{n}=3)$. These features are consistent with the presence of fructokinase activity in the 


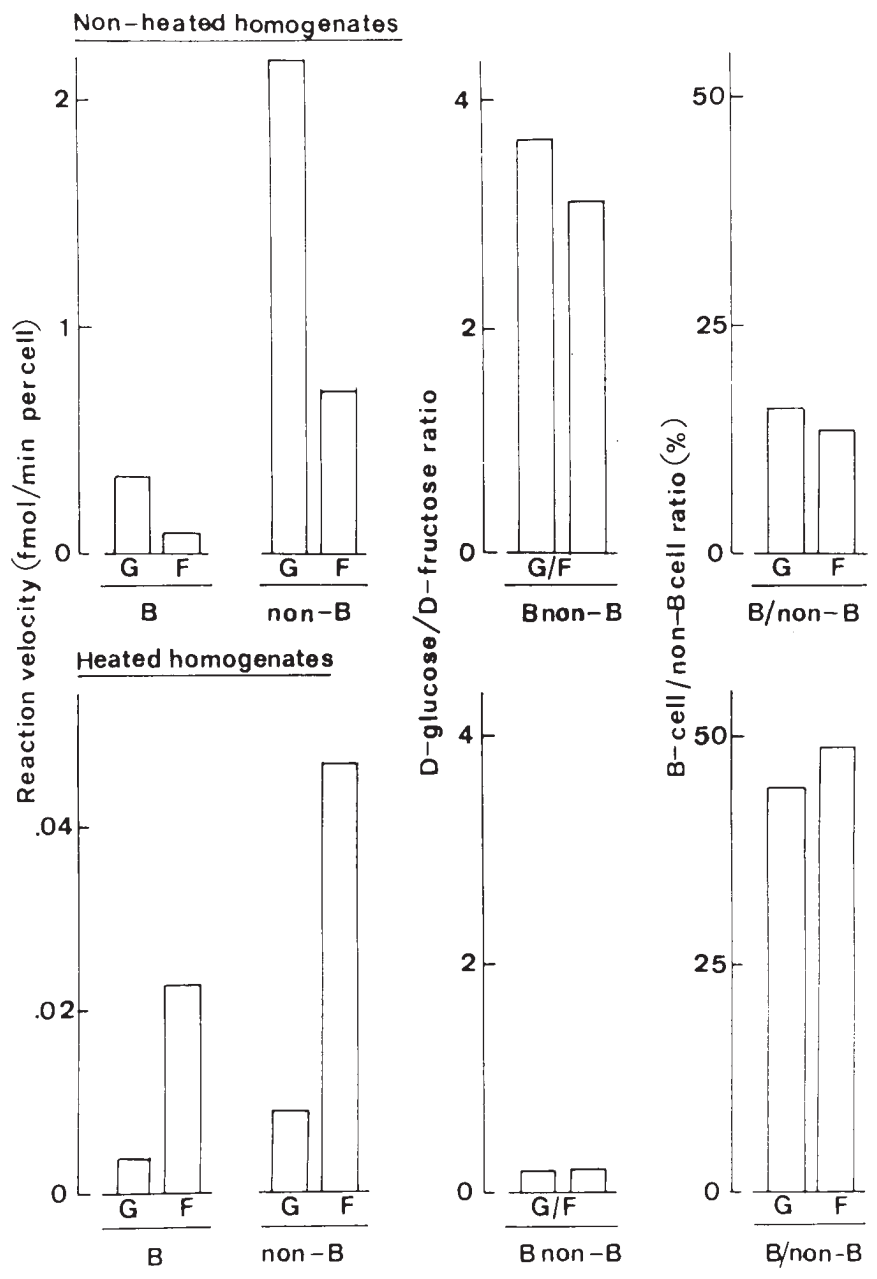

Figure 2. Phosphorylation of D-glucose (G) and D-fructose (F), both tested at a $1.0 \mathrm{mM}$ concentration, by fresh (upper panel) or heated (lower panel) homogenates of $\mathrm{B}$ and non-B islet cells in a representative experiment.

heated islet homogenates. Such a view was borne out by the following findings. Prior heating of the islet homogenates for 5 min at $70^{\circ} \mathrm{C}$ abolished D-glucose phosphorylation. In the presence of $\mathrm{K}^{+}$, it decreased $\mathrm{D}$-fructose phosphorylation to $4.24 \pm 0.89 \%(n=6 ; p<0.001)$ of the paired value found in fresh homogenates. Such a decrease was even more pronounced in the absence of $\mathrm{K}^{+}$, in which case the heated/fresh ratio in reaction velocity averaged $1.70 \pm 1.10 \%(\mathrm{n}=3)$, as distinct $(\mathrm{p}<0.05)$ from $5.90 \pm 0.89 \%(\mathrm{n}=3)$ found within the same experiment(s) in the presence of $\mathrm{K}^{+}$. Most importantly, in the presence of D-mannoheptulose, the heated/fresh ratio in $\mathrm{D}$ fructose phosphorylation averaged $66.15 \pm 6.89 \% \quad(n=3$; $\mathrm{p}<0.05)$, a value about ten times higher $(\mathrm{p}<0.001)$ than that found within the same experiment(s) in the absence of the ketoheptose. Fig. 1 illustrates the close analogy between pancreatic islets and the whole pancreas in terms of the effects of heating upon D-fructose phosphorylation in the presence of $\mathrm{K}^{+}$, absence of $\mathrm{K}^{+}$or presence of D-mannoheptulose.

Purified $B$ and non-B islet cells. In the last set of experiments in this series, the phosphorylation of D-glucose and D-fructose was compared in semi-purified B and non-B islet cells. Fig. 2 illustrates the results of a representative experiment. In nonheated homogenates of purified B and non-B islet cells,

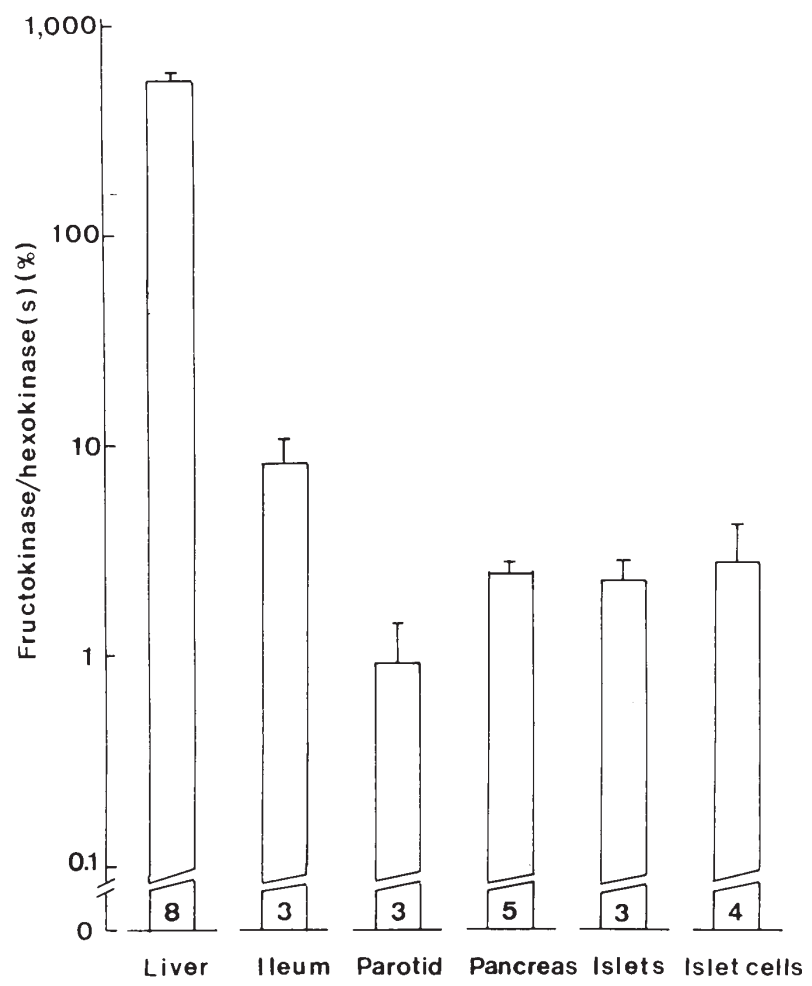

Figure 3. Paired ratio between the activity of fructokinase, as assessed by the phosphorylation of $\mathrm{D}$-fructose $(1.0 \mathrm{mM})$ by heated homogenates incubated in the presence of $\mathrm{K}^{+}$, and that of hexokinase isoenzyme(s), as estimated by the phosphorylation of D-glucose (also $1.0 \mathrm{mM}$ ) by non-heated homogenates. Mean values $( \pm$ SEM) are expressed as a percentage, ranged on a logarithmic scale and refer to the number of individual observations indicated at the bottom of each column.

respectively, the phosphorylation of D-glucose $(1.0 \mathrm{mM})$ was $4.46 \pm 0.79$ and $3.02 \pm 0.08$ times higher ( $n=2$ in both cases) than that of D-fructose (also 1.0 mM). Expressed per cell, the phosphorylation of D-glucose was $5.37 \pm 0.89$ times higher in non-B islet cells than in B cells examined within the same experiment(s). This suggests a higher specific activity of the low-Km hexokinase in the former than latter cells. After heating for $5 \mathrm{~min}$ at $70^{\circ} \mathrm{C}$, the phosphorylation of D-glucose was decreased to $2.25 \pm 0.96 \%(n=4 ; p<0.001)$ of the paired value found prior to heating. In the case of D-fructose, however, such a percentage was 6.09 \pm 2.07 times higher (d.f. $=4 ; \mathrm{p}<0.05$ ) than that found with D-glucose. In these two respects, no significant difference was found between $\mathrm{B}$ and non-B islet cells. These findings are compatible, therefore, with the presence of a limited contribution of fructokinase to the phosphorylation of D-fructose in islet cell homogenates. The major fraction of D-fructose phosphorylation by nonheated islet cell homogenates appears attributable, however, to heat-sensitive enzymes, e.g. hexokinase isoenzyme(s).

Comparison between different cell types. Table I shows the protein content and rates of D-glucose $(1.0 \mathrm{mM})$ and Dfructose $(1.0 \mathrm{mM})$ phosphorylation in fresh homogenates of liver, ileum, parotid gland, pancreas and pancreatic islets. The protein content of islet cells averaged $249 \pm 29 \mathrm{ng}$ per $10^{3}$ cells $(n=4)$. Incidentally, the protein content in heated homogenates of liver, ileum, parotid gland, pancreas, pancreatic islets and 
Table I. Protein content and hexose phosphorylation rate in fresh homogenates.

\begin{tabular}{lccc}
\hline Tissue & $\begin{array}{c}\text { Protein content } \\
(\mathrm{ng} / \mu \text { g wet weight }) \\
(\mathrm{ng} / \text { islet })\end{array}$ & $\begin{array}{c}\text { D-glucose phosphorylation } \\
(\text { pmol/min per } \mu \text { g protein) }\end{array}$ & $\begin{array}{c}\text { D-fructose phosphorylation } \\
\text { (pmol/min per } \mu \text { g protein) }\end{array}$ \\
\hline Liver & $109 \pm 15(12)$ & $4.05 \pm 0.35(8)$ & $25.81 \pm 3.63(11)$ \\
Ileum & $39 \pm 4(3)$ & $30.13 \pm 2.69(3)$ & $19.56 \pm 3.34(3)$ \\
Parotid gland & $84 \pm 22(3)$ & $16.88 \pm 2.01(3)$ & $8.84 \pm 2.56(3)$ \\
Pancreas & $123 \pm 12(12)$ & $21.73 \pm 3.69(8)$ & $14.76 \pm 1.81(11)$ \\
Islets & $716 \pm 68(7)$ & $15.07 \pm 1.81(3)$ & $11.49 \pm 0.91(6)$ \\
\hline
\end{tabular}

purified B-cells averaged $69.4 \pm 5.0 \%(n=39 ; \mathrm{p}<0.001)$ of the paired value found in fresh homogenates.

Relative to protein content, the phosphorylation of Dglucose $(1.0 \mathrm{mM})$ by fresh homogenates was lowest in liver and highest in ileum, with in-between values in parotid glands, pancreas and pancreatic islets. In the case of D-fructose $(1.0 \mathrm{mM})$, the highest mean value was found in liver and the lowest in parotid gland.

In order to compare, in each cell type, the activity of fructokinase to that of hexokinase isoenzyme(s), the reaction velocity recorded in the presence of D-fructose $(1.0 \mathrm{mM})$ and $\mathrm{K}^{+}$using heated homogenates was expressed relative to the paired value found in the presence of D-glucose (also $1.0 \mathrm{mM}$ ) with nonheated homogenates. As illustrated in Fig. 3, such a paired ratio ranged between the extreme values of $548 \pm 45 \%(n=8)$ in liver homogenates and $0.93 \pm 0.52 \%(n=3)$ in parotid gland homogenates. The mean ratios found in pancreas, islets, purified islet B and non-B cells were not significantly different from one another with an overall mean value of $2.57 \pm 0.46 \%$ $(n=12)$.

Last, in order to estimate the specific activity of fructokinase in the different cell types, the reaction velocity recorded in the presence of $\mathrm{D}$-fructose $(1.0 \mathrm{mM})$ and $\mathrm{K}^{+}$in heated homogenates) was expressed relative to protein content (as measured in the corresponding fresh homogenate). Such a specific activity, expressed as nmol/min per mg protein ranged between the extreme mean values of $21.54 \pm 2.47(n=11)$ in liver and $0.158 \pm 0.089(\mathrm{n}=3)$ in parotid gland. In ileum, pancreas and islets, it averaged, respectively, $2.45 \pm 0.53(\mathrm{n}=3)$, $0.82 \pm 0.11(\mathrm{n}=11)$ and $0.46 \pm 0.07(\mathrm{n}=6) \mathrm{nmol} / \mathrm{min}$ per $\mathrm{mg}$ protein. In this respect, the differences between liver versus ileum $(\mathrm{p}<0.005)$, ileum versus pancreas $(\mathrm{p}<0.001)$, pancreas versus islets $(\mathrm{p}<0.05)$ and islets versus parotid gland $(\mathrm{p}<0.05)$ were all statistically significant. Such a specific activity was not significantly different, however, in B and non-B cells (e.g. $0.14 \pm 0.01 \mathrm{nmol} / \mathrm{min}$ per $\mathrm{mg}$ protein in the experiment illustrated in Fig. 2).

\section{Discussion}

The phosphorylation of D-glucose, at the low concentration of D-glucose $(1.0 \mathrm{mM})$ used in the present experiments, informs mainly on the activity of low-Km hexokinase isoenzyme(s).
In this respect, the lower specific activity $(\mathrm{p}<0.001)$ found in the liver than in other organs (Table I) and the lower activity found in purified B islet cells than in non-B islet cells is consistent with a relatively low activity of the low-Km hexokinase(s), as distinct from high-Km glucokinase, in hepatocytes and insulin-producing islet B cells.

Relative to the activity of the hexokinase isoenzyme(s), as assessed by the phosphorylation of D-glucose $(1.0 \mathrm{mM})$ by fresh homogenates, that of fructokinase, as estimated from the phosphorylation of D-fructose (also $1.0 \mathrm{mM}$ ) by heated homogenates, displayed the following hierarchy: liver $>$ ileum $>$ pancreas $\sim$ islets $\sim$ B and non-B islet cells $\geq$ parotid gland. A comparable hierarchy prevailed when the specific activity of fructokinase was estimated from the phosphorylation of D-fructose $(1.0 \mathrm{mM})$ in the presence of $\mathrm{K}^{+}$by heated homogenates and the protein content of the corresponding non-heated homogenates.

In the heated homogenates of either liver, pancreas or islets, the absence of $\mathrm{K}^{+}$decreased, but did not abolish, the phosphorylation of $\mathrm{D}$-fructose. Thus, pooling the results recorded in these three cases, the reaction velocity measured in the absence of $\mathrm{K}^{+}$averaged $25.3 \pm 8.0 \%(\mathrm{n}=9)$ of the paired value found in the presence of $\mathrm{K}^{+}$. Such a percentage is indeed significantly different from both unity $(\mathrm{p}<0.001)$ and zero $(\mathrm{p}<0.02)$. This finding is consistent with the knowledge that other monovalent cations than $\mathrm{K}^{+}$, such as $\mathrm{Na}^{+}$contributed by both the ATP salt and $\mathrm{NaOH}$ used to bring the $\mathrm{pH}$ of the Hepes buffer to 7.5 , may to a certain extent substitute for $\mathrm{K}^{+}$to allow the expression of fructokinase catalytic activity (21).

At this point, it should be underlined that the present study does not inform on the isoform(s) of fructokinase found in each cell type. According to Hayward and Bonthron (22), in both rat and human, tissues expressing high levels of fructokinase (liver, kidney, duodenum) utilize exclusively the $3 \mathrm{c}$ exon isoform, while all other tissues (except pancreas) which express fructokinase at a low level used the 3 a exon isoform. In the pancreas, a mixture of the two isoforms was observed, possibly reflecting low expression of the $3 \mathrm{a}$ form in exocrine pancreatic cells and higher expression of the $3 \mathrm{c}$ form in islet B-cells (22).

In both pancreatic gland and islet homogenates, but not in liver homogenates, prior heating of the homogenates decreased to a limited extent the phosphorylation of D-fructose as measured in the presence of D-mannoheptulose (Fig. 1). Under 
this experimental condition, the heated/fresh paired ratio in reaction velocity averaged $70.1 \pm 8.1 \%$ (pooled results recorded in pancreatic gland and islet homogenates; $n=6$; $\mathrm{p}<0.02)$. This is consistent with the knowledge that Dmannoheptulose, at the concentration tested in the present study, severely inhibits but does not totally suppress the phosphorylation of hexoses by hexokinase(s) (23).

As already alluded to, in the non-heated homogenates of islet cells, the phosphorylation of D-glucose, as well as that of D-fructose, was higher in non-B cells than in B cells (Fig. 2), with a paired ratio of $6.84 \pm 0.57(n=2)$. This suggests a higher specific activity of the low-Km hexokinase in non-B cells than in islet B cells. The fact that this ratio was comparable in the case of D-glucose and D-fructose phosphorylation is consistent with the view that the latter enzyme was mainly responsible for the phosphorylation of D-fructose in the non-heated homogenates of islet cells (2).

In conclusion, the present study confirms the presence of fructokinase in rat pancreatic islets. It documents that the specific activity of fructokinase is lower in the islets than in liver, ileum or the whole pancreatic gland, but higher than in the parotid gland. It also suggests that there is no obvious difference between B and non-B islet cells in terms of either the specific activity of fructokinase or its activity relative to that of hexokinase isoenzyme(s).

\section{Acknowledgements}

This study was supported by grants from the Belgian Foundation for Scientific Medical Research (3.4517.02), the French National Institute of Health and Medical Research (INSERM, France), the French Community of Belgium and the National Foundation for Scientific Research (FNRS, Belgium). We are grateful to M. Mahy for technical assistance and C. Demesmaeker for secretarial help.

\section{References}

1. Malaisse WJ, Malaisse-Lagae F, van Schaftingen E and Davies DR: Presence of fructokinase in pancreatic islets. FEBS Lett 255: 175-178, 1989.

2. Sener A, Giroix M-H and Malaisse WJ: Hexose metabolism in pancreatic islets. The phosphorylation of fructose. Eur J Biochem 144: 223-226, 1984.

3. Scruel O, Sener A and Malaisse WJ: Glucose-induced positive cooperativity of fructose phosphorylation by human B-cell glucokinase. Mol Cell Biochem 175: 263-269, 1997.

4. Moukil MA and van Schaftingen E: Analysis of the cooperativity of human B-cell glucokinase through the stimulatory effect of glucose on fructose phosphorylation. J Biol Chem 276: 3872-3878, 2001.

5. Jijakli H, Courtois P, Zhang H-X, Sener A and Malaisse WJ: Anomeric specificity of the stimulatory effect of D-glucose on D-fructose phosphorylation by human liver glucokinase. J Biol Chem 278: 4531-4535, 2003.
6. Jijakli H, Sener A and Malaisse WJ: Modulation by D-glucose anomers of the effect of D-fructose upon ${ }^{45} \mathrm{Ca}$ efflux from prelabelled rat pancreatic islets. Int J Mol Med 12: 513-515, 2003.

7. Malaisse WJ, Malaisse-Lagae F, Davies DR, Vandercammen A and van Schaftingen E: Regulation of glucokinase by a fructose1-phosphate-sensitive protein in pancreatic islets. Eur J Biochem 190: 539-545, 1990.

8. Sener A and Malaisse WJ: Hexose metabolism in pancreatic islets: apparent dissociation between the secretory and metabolic effects of D-fructose. Biochem Mol Med 59: 182-186, 1996.

9. Viñambres C, Villanueva-Peñacarrillo ML, Valverde I and Malaisse WJ: Failure of D-fructose to stimulate protein biosynthesis in pancreatic islets. Biochem Mol Biol Int 41: 571-574, 1997.

10. Sener A, Leclercq-Meyer V and Malaisse WJ: Immediate and delayed effects of D-fructose upon insulin, somatostatin and glucagon release by the perfused rat pancreas. Endocrine 24: 73-81, 2004.

11. Prieto PG, Cancelas J, Villanueva-Peñacarrillo ML, Valverde I and Malaisse WJ: Plasma D-glucose, D-fructose and insulin responses after oral administration of D-glucose, D-fructose and sucrose to normal rats. J Am Coll Nutr 23: 414-419, 2004.

12. Giroix M-H, Scruel O, Ladrière L, Sener A, Portha B and Malaisse WJ: Metabolic and secretory interactions between Dglucose and D-fructose in islets from GK rats. Endocrinology 140: 5556-5565, 1999.

13. Scruel O, Giroix M-H, Sener A, Portha B and Malaisse WJ: Metabolic and secretory response to D-fructose in islets from adult rats injected with streptozotocin during the neonatal period. Mol Gen Metab 68: 86-90, 1999.

14. Giroix M-H, Scruel O, Courtois P, Sener A, Portha B and Malaisse WJ: Comparison between D- $\left[3-{ }^{3} \mathrm{H}\right]-$ and D- $\left[5-{ }^{3} \mathrm{H}\right]-$ glucose and fructose utilization in pancreatic islets from control and hereditarily diabetic rats. Arch Biochem Biophys 408: 111-123, 2002.

15. Scruel O, Sener A and Malaisse WJ: Double purification of radiolabelled D-fructose by high performance liquid chromatography for tracing its metabolism. J Chromatogr A 847: 53-57, 1999.

16. Malaisse-Lagae $\mathrm{F}$ and Malaisse WJ: Insulin release by pancreatic islets. In: Methods in Diabetes Research. Larner J and Pohl SL (eds). John Wiley \& Sons, New York, pp147-152, 1984.

17. Ramirez R, Jijakli H, Zhang H-X, Bakkali-Nadi A, Sener A and Malaisse WJ: Effects of D-mannoheptulose upon D-glucose metabolism in pancreatic B and non-B islet cells. Int J Mol Med 9: 159-163, 2002.

18. Alejandro RI, Shienvold FL, Hajek SA, Pierce M, Paul R and Mintz DH: A ganglioside antigen on the rat pancreatic $\mathrm{B}$ cell surface identified by monoclonal antibody R2D6. J Clin Invest 74: 25-38, 1984

19. Giroix M-H, Sener A, Pipeleers DG and Malaisse WJ: Hexose metabolism in pancreatic islets. Inhibition of hexokinase. Biochem J 223: 447-453, 1984.

20. Lowry OH, Rosebrough NJ, Farr AL and Randall RJ: Protein measurement with the Folin phenol reagent. J Biol Chem 153: 265-275, 1951.

21. Raushel FM and Cleland WW: Bovine liver fructokinase: purification and kinetic properties. Biochemistry 16: 2169-2175, 1977.

22. Hayward BE and Bonthron DT: Structure and alternative splicing of the ketohexokinase gene. Eur J Biochem 257: 85-94, 1977.

23. Scruel O, Vanhoutte C, Sener A and Malaisse WJ: Interference of D-mannoheptulose with D-glucose phosphorylation, metabolism and functional effects: comparison between liver, parotid cells and pancreatic islets. Mol Cell Biochem 187: 113-120, 1998. 